\title{
Edistystä ja taka-askeleita perheellisten verotuksessa vuosina 1941-45
}

Kirjoittanut V. J. Sukselainen.

Kun hallitus vuonna 1925 antoi ensimmäisen esityksensä erityisen lisäveron säätämisestä perheettömille, kirjoitti E. Nevanlinna: »Mainittu esitys saattaa oikeastaan olla vain alkuna asian nykyistä oikeampaan järjestämiseen meillä. Jatkona täytyy olla koko tulo- ja omaisuusverolain tarkistus - - Tällainen tarkistus tulee sitä tarpeellisemmaksi, jos, kuten näyttää, verotaakkaa on pakko meillä edelleen lisätä.. ${ }^{1}$ ) Eri yhteyksissä sukeltautuikin kysymys perheellisten verotuksesta kerran toisensa jälkeen esille, vaikkakin parannukset supistuivat kovin vähiin. Kunnallisverotuksessa säilyivät vuonna 1922 säädetyt lapsivähennykset 1940luvulle saakka ja valtionverotuksessakaan ei tapahtunut juuri muuta, kuin että perheettömille säädettiin lisävero vuonna 1935 ja lapsivähennys korotettiin samalla 1.200 markasta 2.500 markkaan.

Sikäli kuin suuren yleisön mielenkiinto jo 1930-luvun loppupuolella alkoi kohdistua väestöpoliittisiin kysymyksiin, alettiin entistä laajemmissa pïreissä kiinnittää huomiota siihen, että lasten kasvattamisesta aiheutuvaa suorituskyvyn alenemista ei riittävästi otettu huomioon verotuksessa. Tätä asiaa käsiteltiin esim. vuonna 1937 asetetussa väestökomiteassa, vaikka komitean keskustelut eivät ehtineetkään kypsyä mietintöasteelle, ennenkuin sotavuodet tulivat väliin.

1) Kansantaloudellinen Aikakauskirja 1925, s. 203. 
Väestöliitossa otettiin verotusasia heti alussa esille. Tarkoitukseni oli pitää asiasta esitelmä Kansantaloudellisessa Yhdistyksessä jo kevättalvella 1941. Eräistä käytännöllisistä syistä esitelmä kuitenkin siirtyi syksyyn ja kun välillä olin tullut kutsutuksi asepalvelukseen, saatoin pitää sen vasta marraskuun lopulla $1941 .^{2}$ ) Asia tuli tällöin julkiseen keskusteluun monessa muodossa. Väestöliitto $\mathrm{mm}$. kääntyi valtiovarainministeriön puoleen pyytäen, että kesällä 1941 asetetulle verokomitealle, jonka puheenjohtajana toimi valtioneuvos J. K. Paasikivi, annettaisiin tehtäväksi syventyä perheellisten verotuskysymykseen sen koko laajuudessa.

Kun verotaakka näihin aikoihin alkoi jyrkästi nousta, tämä oli omiaan tekemään kysymyksen perheellisten verotuksesta ajankohtaiseksi. Näin alkoi kehitys, joka parin lähimmän vuoden aikana johti tärkeisiin uudistuksiin niin valtion kuin kunnallisessakin verotuksessa.

\section{KUNNALLISVEROTUS.}

Edustaja Kajalan lakialoite. Edustaja Kajalan ja eräiden muiden helmikuussa 1941 tekemän lakialoitteen pohjalla oli kunnallisverotuksen uudistus tullut eduskunnassa käsiteltäväksi. Varsinkin loppuvuodesta 1941 teki maan sosiaalidemokraattinen lehdistö voimakasta propagandaa kunnallisten perus- ja lapsivähennysten korottamisen puolesta. Tähän valistustyöhön yhtyi Väestöliitto omalla rintamallaan varsinkin lapsivähennysten kohdalla. Tuloksena olikin, että eduskunta tammikuun 88 päivänä 1942 päätti kehoittaa hallitusta antamaan kiireellisesti eduskunnalle esityksen »kunnallisverolakien muuttamisesta niin, että perus- ja lapsivähennysten määrät korotetaan muuttunutta hinta- ja elintasoa vastaaviksi».

Lapin läänin kuntien liiton tutkimus. Hallitus antoi sittemmin verokomitean tehtäväksi tällaisen ehdotuksen valmistamisen. Samanaikaisesti kiinnitettiin Väestöliiton taholta Pohjois-Suomen kunnallismiesten huomiota siihen, että kysymys kunnallisverotuksen uudistamisesta perheellisiä tyydyttävällä tavalla ei ilmeisestikään ole ratkaistavissa maan köyhimpien ja lapsirikkaimpien

2) Kansantaloudellinen Aikakauskirja 1942, s. 19-39. 
kuntien kohdalta muuten kuin kunnallisen verorasituksen tasoituksen avulla. Tällaisen uudistuksen valmisteluihin olisi siitä syystä ajoissa ryhdyttävä. Lapin läänin kuntien liitto oivalsikin asian tärkeyden ja toimeenpani tutkimuksen siitä, mitä edustaja Kajalan lakialoitteessa esitetty perus- ja lapsivähennysten korotus vaikuttaisi verotukseen eräissä Lapin läänin kunnissa ja vastaavasti eräissä Etelä-Suomen kunnissa. Tutkimus jäi liian suppeaksi muodostuakseen tehokkaaksi aseeksi siinä taistelussa, joka kunnallisen verorasituksen tasoituksen aikaansaamiseksi olisi tarpeellista aloittaa. Siitä kävi kuitenkin selvästi ilmi asian ydin. Köyhillä seuduilla, joilla lapsirikkaus on yleistä, lapsivähennyksiä ei voida nykyisen järjestelmän vallitessa nostaa niin suuriksi kuin lasten aiheuttama veronmaksukyvyn aleneminen vaatisi. Jos tätä yritettäisiin, tuloksena olisi pääasiassa vain veroäyrin hinnan kohoaminen.

Voimassa olleet vuoden 1922 säännökset. Ne kunnallisverolakien määräykset, joiden uudistamista verokomitea vuoden 1942 kuluessa joutui harkitsemaan, olivat auttamattomasti vanhentuneet. Vuodesta 1922 oli maalaiskunnissa ollut voimassa säännös, jonka mukaan verovelvollisen henkilön tulosta, jos se määrättyjen vähennysten jälkeen ei ollut yli 6.000 markan, oli tehtävä ns. perusvähennys, joka kunnanvaltuuston vuosittain tekemän päätöksen mukaisesti vaihteli, mutta oli kuitenkin vähintään 1.500 markkaa ja enintään 2.500 markkaa. Niille verovelvollisille, jotka eivät saaneet tehdä lapsivähennystä, perusvähennys muodostui toimeentulominimiksi. Jos perusvähennys oli määrätty alimmaksi mahdolliseksi eli 1.500 markaksi, tämä merkitsi, että henkilöllä, jonka tulot olivat 1.600 markkaa vuodessa, oli vähennyksen jälkeen 1 äyri veronalaista tuloa ja hänelle oli siis pantava vero, jos lain kirjainta noudatettiin.

Kaupunkikunnissa tilanne oli käytännöllisesti katsoen sama, vaikka siellä olivat kysymyksessä vähän suuremmat luvut. Henkilö, jonka tulo ei ollut yli 9.000 markan, sai lukea hyväkseen perusvähennyksen, joka vaihteli 2.000 markasta 4.000 markkaan. Verovelvollisuus siis kaupungeissa alkoi 2.100 markan vuositulosta. Tämän lisäksi on huomattava, että maaseudulla henkilöt, joiden vuositulo oli $6.000-18.000$ markkaa, sekä kaupungeissa $9.000-20.000$ mar- 
kan tulon omaavat verovelvolliset saivat $9 / 10-1 / 10$ perusvähennystä erityisen asteikon mukaan.

Tärkeämpi kuin perusvähennys oli perheellisten kannalta Lapsivähennys. Perusvähennyksen tehtävähän on toimia eräänlaisena progression korvikkeena, jotta kaikkein pienimpiä tuloja ei verotettaisi yhtä raskaasti kuin muita. Lapsivähennyksen tarkoitus taas on lieventää verotusta niin paljon kuin lasten kasvattamisen on katsottava veronmaksukykyä alentavan. Lapsivähennykset tulivat meillä kunnallisessa verotuksessa käytäntöön vuonna 1922, jolloin säädettiin, että perusvähennyksen teon jälkeen verovelvollisen henkilön tuloa oli vielä vähennettävä vähintään $500^{\prime}$ ja enintään 1.200 markalla jokaiselta .lapselta, jota hän elatusvelvollisuutensa nojalla on elättänyt ja joka verovuoden päättyessä ei ollut täyttänyt 15 vuotta.

Vähennysten tekojärjestys oli periaatteellisesti virheellinen. Koska lapsivähennyksen tehtävänä on mưuttaa kaksi näennäisesti yhtä suurta, mutta erilaista veronsuorituskykyä edustavaa tuloa suorituskyvyltään toisiinsa verrattaviksi, se olisi pitänyt tehdä ennen progressiota edustavaa perusvähennystä. Kun näin ei tehty, perheelliset joutuivat kärsimään. Monet suuriperheiset, jotka jäivät kokonaan osattomiksi perusvähennyksestä, olisivat sen saaneet, jos lapsivähennys olisi tehty ennen. Toiset taas olisivat saaneet suuremman perusvähennyksen, jos vähennykset olisi tehty loogillisessa järjestyksessä.

Perus- ja lapsivähennysten korottaminen vuonna 1943. Kun verokomitea marraskuussa 1942 jätti ehdotuksensa kunnallisten perus- ja lapsivähennysten korottamiseksi, se ehdotti perusvähennyksiksi maalaiskunnissa $3.000-6.000$ markkaa ja kaupunkikunnissa $4.000 \quad 8.000$ markkaa. Lapsivähennysten teossa esitettiin nyt myös paikkakuntien kalleussuhteet siten huomioon otettaviksi, että vähennys olisi maalaiskunnissa $2.000-3.000$ markkaa ja kaupunkikunnissa $2.500 \quad 4.000$ markkaa lapselta. Ehdotus oli siis kaikin tavoin varovainen. Muuttuneesta hintatasosta huolimatta perusvähennykset komitean ehdotuksessa olivat pienemmät kuin Tannerin hallituksen vuonna 1927 antamassa esityksessä. Sananmukaisesti ottaen saattaisi päätellä komitean arvelleen yksinäisen 
henkilön elävän maaseudulla 250 markan ja kaupungissa 334 markan kuukausitulolla ja tulevan veronmaksukykyiseksi, kun palkka alkaa tästä vähänkin nousta. Komitean puolustukseksi on kuitenkin sanottava, että se mietinnössään kyllä totesi alimmat elinkustannukset tätä suuremmiksi, mutta pelkäsi kuntien talouden liikaa järkkyvän, jos järjestelmää uusimatta koetetaan perus- ja lapsivähennyksiä korottaa enemmän.

Antaessaan joulukuussa 1942 eduskunnalle esityksen asiasta hallitus esitti maalaiskunnissa samaa perusvähennystä kuin verokomiteakin, mutta korotti kaupunkien kohdalla alirajaa ehdottaen perusvähennykseksi $5.000-8.000$ markkaa. Niinikään korotti hallitus lapsivähennystä esittäen maalaiskunnissa $2.000-4.000$ markan ja kaupunkikunnissa $3.000-6.000$ markan vähennystä jokaiselta lapselta, joka ennen verovuoden alkua ei ole täyttänyt kuuttatoista vuotta.

Verokomitea ei kummallista kyllä kiinnittänyt huomiota vähennysten tekojärjestykseen, vaikka laki- ja talousvaliokuntakin vuonna 1941 oli edustaja Kajalan lakialoitetta käsitellessään epäkohdan huomannut. Hallituksen esityksen ensimmäinen luonnos sisälsikin vähennykset verokomitean esittämässä entisessä järjestyksessä. Ennen asian tuloa lopulliseen käsittelyyn valtioneuvostossa sain kuitenkin tilaisuuden jättää valtiovarainministerille muistion, jossa perustelin niitä näkökohtia, jotka puoltavat lapsivähennyksen tekemistä ennen perusvähennystä. Kun eräät sosiaalidemokraattisen eduskuntaryhmän veroasiaintuntijat olivat samalla kannalla, ministeri Tanner antoikin muokata hallituksen esityksen uudelleen ja muuttaa vähennysten tekojärjestystä.

Tässä samassa yhteydessä ilmaantui lapsivähennyspykälään sitä valtiovarainministeriössä muokattaessa eräs uusi periaate, joka luonnollisestikaan ei voinut eduskuntakäsittelyn kiirastulta läpäistä. Hallitus näet esitti, että vähennys saataisiin tehdä myös aviovaimon osalta. Esityksen perusteluissa sanottiin: »Vaikka sellaisen verovelvollisen, jolla on elätettävänään kotona oleva vaimo, veronmaksukyky on huomattavasti vähäisempi kuin yhtä suuret tulot omaavan yksinäisen veronmaksajan, ei tätä eroa meidän voimassa olevassa laissamme, toisin kuin useiden muiden maiden verolainsäädännössä, oteta lainkaan huomioon». Hallituksen esityksen laa- 
tijat tai heidän asiantuntijansa, jotka tämän säännöksen olivat muiden maidan lainsäädännössä havainneet ja edellämainituin epäonnistunein perusteluin yrittivät sijoittaa sen meidän lainsäädäntöömme, olivat epäilemättä toimineet hyvässä tarkoituksessa, halunneet keventää verorasitusta perheenhuoltajain kohdalta. Tämä hyvä tarkoitus jäi kuitenkin kokonaan varjoon sen närkästyksen rinnalla, minkä hallituksen esityksen edellämainittu sanamuoto naisten keskuudessa herätti. Maan pätevimmät naispuoliset veroasiantuntijat osoittivat eri puolueitten lehdissä, että vaimo ei suinkaan merkitse miehen veronmaksukyvyn alenemista. Silloinhan vaimon kuolema merkitsisi parasta, mitä aviomies veronmaksukykyänsä ajatellen saattaa toivoa, ja näinhäin ei ole. Annettakoon suuriperheisille veronhelpotusta lapsiluvun perusteella. Vaimon' kohdalta riittää, että hänen kotitaloudessa suorittamansa työ edelleenkin jää verovapaaksi, kuten se tähän saakka on ollut.

Laki- ja talousvaliokunta poistikin esityksestä vaimon kohdalta tehtävän vähennyksen, muttạ esitti perus- ja lapsivähennykset muuten hyväksyttäväksi hallituksen esityksen mukaisina. Näin eduskunta tekikin ja laki voitiin antaa maaliskuussa 1943. Sitä ei kuitenkaan enää ehditty soveltaa vuoden 1943 kunnallistaksoituksessa, kuten hallitus esitystä antàessaan oli ajatellut, vaan vasta vuonna 1944.

Uudistuksen puolinaisuus. Vuoden 1943 alkupuolella tapahtunut kunnallisverolain uudistus merkitsi perheellisille verovelvollisille suurta huojennusta, kuten oheisesta asetelmasta käy selville. Oli astuttu aimo askel suorituskykyisyyden mukaista verotusta kohden. Ei kuitenkaan pidä unohtaa, että uudistusta toimeenpantaessa oltiin täysin tietoisia siitä, että veroa uudistuksen jälkeenkin jouduttiin panemaan henkilöille, joilla ei voi katsoa olevan mitään veronmaksukykyä muussa kuin siinä tapauksessa, että heidän tulonsa ón ilmoitettu väärin tai heidän nauttimansa luontoisedut arvioitu liian mataliksi.

Järjestelyä voitiin puolustaa ainoastaan sillä, että koko kunnallisverotus on uudistamisen tarpeessa, koska perheellisyyden aiheuttamaa veronmaksukyvyn alenemista ei köyhissä lapsirikkaissa kunnissa voida ottaa riittävästi huomioon, ennenkuin saadaan aikaan kunnallisen verorasituksen tasoitus. Tätä kirjoitet- 
Vuoden 1943 kunnallisverouudistuksen merkitys perheellisille.

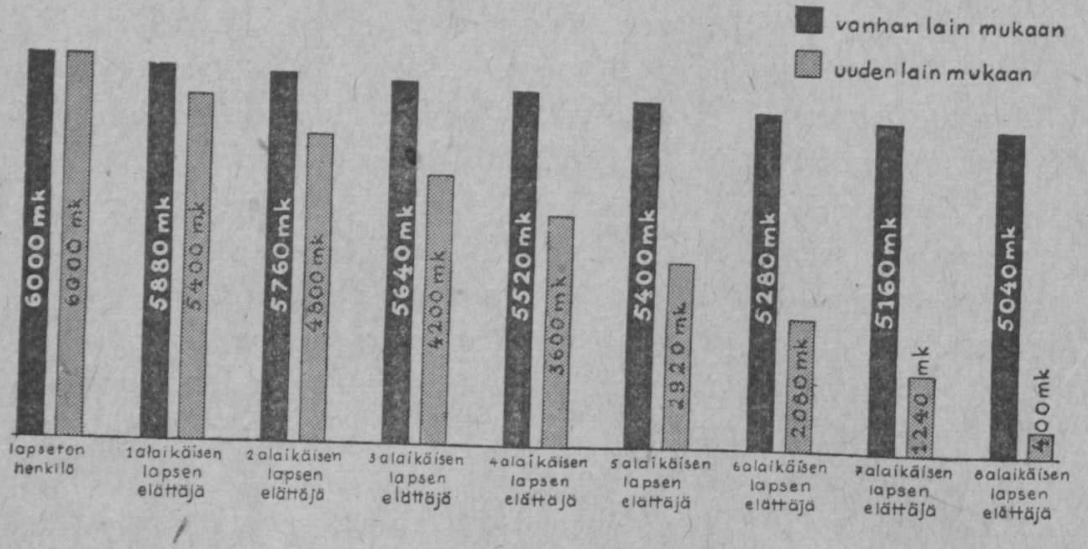

Mustat pylväät: 60.000 markan vuosituloista ennen lapsi- ja perusvähennysten korotusta mennyt kunnallisvero, jos veroäyri on ollut 10 markkaa ja vähennykset myönnetty enimmäismääräisinä.

Harmaat pylväät: 60.000 markan vuositulosta vuonna 1943 toimeenpannun perus- ja lapsivähennysten korotuksen jälkeen menevä vero. Aikaisemmin perusvähennys ei ulottunut tähän tuloluokkaan. Vähennysten tekojärjestyksen muuttaminen on tuonut tämän tuloluokan suuriperheisimmät myös perusvähennyksen piiriin.

taessa on hallituksen esityksen antamisesta kulunut neljättä vuotta, mutta kunnallisverotuksen uudistus viipyy yhä eikä mitään suunnitelmia kunnallisen verorasituksen tasauksen pikaisesta aikaansaamisesta tiettävästi vielä ole olemassa.

Näinä kolmena vuotena on vuoden 1943 uudistus sitävastoin menettänyt merkityksensä rahan arvon alenemisen takia. Tammikuussa 1943, jolloin laki- ja talousvaliokunta päiväsi mietintönsä, elinkustannusindeksi oli 184. Tammikuussa 1946 oli mainittu indeksi kohonnut 423 pisteeseen elikkä noin 130 prosentilla. Tällä kertaa ovat perusvähennykset alimpia vähennysmääriä käyttävissä maalaiskunnissa ja ylimpiä vähennysmääriä käyttävissä kaupunkikunnissa tosiasiallisesti pienemmät kuin ne olivat ennen 
vuoden 1943 korotusta. Perusvähennyksethän nousivat mainittuna vuonna maalaiskunnissa $100-140$ prosentilla ja kaupunkikunnissa 150-100 prosentilla. Vain lapsivähennyksen kohdalla on korotuksesta jotakin jäljellä.

Jo alkusyksystä 1945 hyväksyi eduskunta uudelleen toivomusponnen perus- ja lapsivähennysten korottamisesta muuttuneita olosuhteita vastaaviksi. Kun esitystä ei alkanut kuulua, tehtiin eduskunnassa asiasta kysely (edustaja Kujala ym.). Valtiovarainministerin vastauksessa, joka jaettiin vuoden 1946 alussa, koetetaan osoittaa, että asia ei ole vielä kiireellinen. Ensinnä huomautetaan siitä, että korotetut lapsi- ja perusvähennykset ovat olleet voimassa vasta niin lyhyen ajan, ettei vielä ole voitu saada varmaa kokemusta siitä, mitä ne ovat vaikuttaneet verotaakan jakaantumiseen eri veronmaksajaryhmien kesken. Tämä perustelu tietysti on aiheeton, koska rahan arvon aleneminen jo on ssyönyt» korotukset. Sen ministeri Törngren kai on itsekin huomannut, koska hän vastauksensa loppuosassa myöntää, että elinkustannusten' nousu jo sinänsä riittää tarkistusvaatimuksen perusteluksi. Vähennysten korottaminen edellyttäisi hänen mielestään kuitenkin suurempaa olojen vakaantumista, kuin mitä on tapahtunut. Kun kuluvana vuonna. saaduilla suuremmilla nimellistuloilla maksetaan vuoden 1945 tulojen perusteella pannut kunnallisverot, ministeri katsoo tämän huomattavasti helpottavan verotaakkaa. Tässä on tietysti perää, mutta se ei tee suhdetta perheellisen ja perheettömän verotuksen välillä yhtään oikeudenmukaisemmaksi. Siihen tarvitaan perus- ja lapsivähennysten tarkistusta.

Tällä tarkistuksellakaan ei asiaa ratkaista muuta kuin tilapäisesti. Pyrittäessä perheellisten oikeudenmukaisempaan verottamiseen on kunnallisverotuksen täydellinen uusiminen ja kunnallisen verorasituksen tasauksen käytäntöön ottaminen välttämätöntä. Se on kiireellisimpiä ratkaisuaan odottavista verokysymyksistä ja koskee erittäin laajoja veronmaksajapiirejä.

\section{TULO- JA OMAISUUSVEROTUS.}

Hallituksen esitys vuonna 1942. Myös tulo- ja omaisuusveron kohdalla aiheutti perhéellisten verotusta koskevan kysymyksen 
esilletulo ja siihen liittynyt julkinen keskustelu myönteistä kehitystä. Hallituksen esitys n;o 1 vuodelta 1942 oli perheellisten kannalta mitä tervetullein. Se sisälsi useita parannusesityksiä, joiden mukaantuloon Väestöliitolla oli ollut tilaisuus välittömästi vaikuttaa. Siinä esitettiin lapsivähennyksen suurentamista, vieläpä siten, että vähennys nousisi lapsiluvun kasvaessa. Kun ns. kalliin paikkakunnan vähennys oli ollut riippumaton perheen suuruudesta ja tästä johtuen tuottanut varsinkin kalleimmilla paikkakunnilla yksinäisille henkilöille kohtuuttoman suuren veronalennuksen, epäkohtaa koetettiin nyt korjata tekemällä lapsivähennys paikkakunnan kalleudesta riippuvaksi. Tulo- ja omaisuusverolaki oli vuodesta 1940 suhtautunut erityisen ynseästi nuoriin perheisiin, kun vanhanpojanveroa oli ruvettu kantamaan siihen saakka, kunnes esikoiselle oli ehditty antaa täysi ja tarvittava elatus täyden kalenterivuoden aikana. Oli useasti sattunut tapauksia, jolloin vanhanpojanveroa oli jouduttu kantamaan perheiltä, joilla oli jo kaksikin lasta. ${ }^{1}$ ) Tämä epäkohta oli nyt myös tarkoitus korjata. Esitys oli niin hyvä kuin kiireelliseltä pikakorjaukselta voi vaatia. Verokomitea sitäpaitsi oli saanut tehtäväkseen tulo- ja omaisuusverolain täydellisen uusimisen.

Hallituksen esitys tulo- ja omaisuusverolain muuttamisesta joutui eduskunnassa vastatuuleen osuuskuntien ja säästöpankkien verotusta koskevalta osaltaan. Estääkseen epämieluisan ratkaisun hallitus peruutti esityksensä. Myöhemmin annettiin kyllä uusi esitys, mutta siihen otettiin vain eräitä lähinnä verotusteknillistä laatua olevia kysymyksiä. Hallitus lienee perustellut perheellisiä koskevien helpotusten poisjättämistä sillä, ettei se voi esittää veron tuottoa vähentäviä muutoksia, koska eduskunta ei ole suostunut näiden vástapainoksi tarkoitettuihin veron tuottoa lisääviin ehdotuksiin. Perheelliset siis saivat maksaa valtiomahtien välisen erimielisyyden asiassa, joka ei millään tavalla koskenut perheellisten verotusta. Väestöliitonkaan taholla ei näinä aikoina pidetty uutta huomattavampaa propagandahyökkäystä tarpeellisena, koska tie-

1) Vrt. V. J. Sukselainen: Keskustelu perheellisten verotuksesta vuonna 1942. Suomalainen Suomi 1942, s. 461. 
dettiin asian olevan verokomitean ohjelmassa. Tyydyttiin vain pitämään yhteyttä tätä kysymystä harrastaviin verokomitean jäseniin ja seuraamaan asian kehittymistä.

Vuoden 1943 tulo- ja omaisuusverolaki. Kesällä 1943 verokomitea jätti valtioneuvostolle ehdotuksensa uudeksi tulo- ja omaisuusverolaiksi. Jos valtioneuvosto edellisenä vuonna oli voinut vähän suurentaa verokomitean esittämiä kunnallisten perus- ja lapsivähennysten määriä, oli komitea tällä kertaa ollut rohkeampi, vieläpä eräissä suhteissa, esim. lapsivähennysten määrään nähden ylittänyt nekin toiveet, joita Väestöliitto oli rohjennut siihen kiinnittää, Voimassaolevan lain mukaan lapsivähennys oli ollut 2.500 markkaa tulosta. Tämä oli perusasteikon mukaan laskien merkinnyt käytännössä tulon suuruudesta riippuen $40-575$ markan suuruista veronhuojennusta lasta kohden. Jos silloiset veronkorotukset otettiin lukuun, vähennys saattoi olla 72 - 1.035 markkaa lasta kohden. Nyt ehdotti verokomitea, että lapsivähennys tehtäisiin verosta ja se olisi 1 prosentti tulosta aina 360.000 markan tuloon saakka, jolloin vähennys muuttuisi kiinteäksi. Näin olisi veronhuojennus tullut olemaan 120-3.600 markkaa lasta kohden.

Toinen merkittävä muutosehdotus oli se, että perheettömien lisävero entisessä muodossaan jäisi pois ja asia järjestettäisiin jakamalla verovelvolliset kolmeen veroluokkaan, joilla kullakin olisi oma veroasteikkonsa. III luokan asteikkoa olisi pidettävä normaaliasteikkona. Se olisi pienien tulojen kohdalla vähän lievempi voimassaolevaa perusasteikkoa sekä yläpäässä vähän raskaampi. Tähän asteikkoon tulisivat yleensä ne, jotka ovat suorittaneen elatusvelvollisuutta vähintään 10 vuotta. Tästä asteikosta taas saisivat alennusta ne, jotka parhaillaan elättävät lapsiaan. Erikoisuutena oli se, että avioliiton solmittuaan pääsisi mutamiksi »koevuosiksi» tämän alimman asteikon piiriin, josta sitten määräajan päätyttyä siirtyisi II veroluokkaan, ellei lapsia olisi syntynyt. II veroluokan asteikko esitettiin jonkin verran lievemmäksi kuin voimassaoleva perusasteikko korotettuna perushankintaverolla ja perheettömien lisäverolla. Sen piiriin tulisivat kuulumaan lapsettomat aviopuolisot siirryttyään pois III veroluokasta sekä alle 24-vuotiaat verovelvolliset. Tulovero I veroluokassa, johon kuuluisivat 24 vuotta täyttäneet henkilöt, jotka eivät ole naimisissa, eivät ole elättäneet 
verovuotena alle 17 vuotiasta lastaan eivätkä vähintään kymmentä vuotta aikaisemmin tällaista elatusta antaneet, esitettiin saman verran II luokan veroa raskaammaksi kuin mitä tämä oli III luokan veroa raskaampi.

Esitys merkitsi siis sitä, että perheettömien lisäveroa itse asiassa korotettaisiin, vaikka se ei enää esiintyisi erityisenä prosenttimääräisenä korotuksena, kuten tähän astí oli ollut asian laita. Parannusta merkitsi myös se, että perheellisyys esitettiin myös otettavaksi omaisuusverotuksessa sikäli huomioon, että veronalaisesta omaisuudesta saisi vähentää 50.000 markkaa, milloin aviopuolisoita yhdessä verotetaan, sekä jokaisen lapsivähennykseen oikeuttavan lapsen osalta 50.000 markkaa. Näin verovapaan omaisuuden yläraja siis nousisi esim. kolmen lapsen perheessä 100.000 markasta 300.000 markkaan.

Ennenkuin uusi tulo- ja omaisuusverolaki marraskuussa 1943 annettiin, verokomitean ehdotus joutui eräiden muodonvaihdosten alaiseksi. Lapsivähennysten kohdalla hallitus hyväksyi komitean linjan, mutta ei rohjennut esittää korkeampaa kuin 1.800 markan vähennystä verosta. Eduskunta vuorostaan tinki tästä taas puolet, joten korkein lapsivähennys tuli olemaan vain 900 markkaa eli neljännes verokomitean ehdottamasta määrästä. Suurempaa vähennystä olisi kyllä voinut pätevästi perustella, mutta väestöpoliittisesti huononnus ei silloisen rahanarvon mukaan merkinnyt kovin paljon. Lapsiperheiden valtaosa kuului alle 90.000 markan tuloluokkiin, joihin tämä huonnonnus ei ulottunut.

Mitä veroluokkajakoon tuli, omaksui hallitus eräitä periaatteita, joita sekä väestöpoliittisesti että suorituskykyisyyttä ajatellen on pidettävä komitean näkökantoja parempina. Keskimmäinen veroluokka, johon komitea oli sijoittanut alle 24-vuotiaat sekä lapsettomat aviopuolisot, puuttui kokonaan hallituksen esityksestä. Nämä henkilöryhmät hallitus sijoitti I veroluokkaan. Tämän jälkeen III luokan järjestysluvuksi tuli II, mutta asteikko pysyi entisellään.

Hallituksen tekemä muutos oli hyvin perusteltu, sillä jos asiaa suorituskykyisyyden kannalta tarkastellaan, alle 24-vuotias on samasta tulosta yhtä suorituskykyinen kuin 24 vuotta täyttänytkin. Tuo aikaisemmasta perheettömien lisäverosta peräisin 
oleva ikäraja perustuu siihen vanhentuneeseen ja vääränä pidettävään käsitykseen, että lisävero olisi jonkinlainen rangaistus avioliiton laiminlyömisestä ja että sitä ei sopisi panna, ennenkuin verovelvollinen on saavuttanut iän, jolloin olisi hyvin ehtinyt solmia avioliiton. Verokomitean ehdottamaa eroa naimisissa olevien lapsettomien ja naimattomien lapsettomien välillä ei myöskään voida tyydyttävästi perustella. Henkilöä, jonka vaimo työskentelee kotona, ei voida pitää vähemmän suorituskykyisenä kuin henkilöä, joka ei ole naimisissa. Onhan vaimon kotitaloudessa suorittama työ kokonaan verovapaa. Vielä vähemmän tähän on syytä sellaisessa tapauksessa, jossa vaimo käy ansiotyössä ja lisää perheen veronmaksukykyä. Eduskunta ei kuitenkaan ottanut näitä Väestöliiton taholta esitettyjä näkökohtia huomioon, vaan siirtyi vanhentuneen verotuspoliittisen ajattelun painosta pois hallituksen linjalta ja omaksui verokomitean käsityksen. Keskimmäinen veroluokka palautettiin esitykseen ja tuli lakiin suunnilleen verokomitean ehdottamassa muodossa.

Omaisuusveron kohdalla verokomitean ehdotus tuli hyväksytyksi sekä hallituksessa että eduskunnassa, vaikka valtiovarainvaliokunta yrittikin saada lapsen osalta tehtävän alennuksen vähennetyksi 25.000 markkaan.

Taka-askel aviopuolisoiden verotuksessa. Paitsi niitä edelläesitettyjä epäkohtia, jotka liittyvăt veroluokkajakoon, uuteen tuloja omaisuusverolakiin jäi eräitä muitakin kohtia, jotka kaipasija omaisuusverolakiin jäi eräitä muitakin kohtia, jotka kaipaisikäsittelyn aikana koetti saada onnellisempaa muotoa. Niinpä siirryttiin aviopuolisoiden verotuksessa askel taaksepäin. Luovuttiin siitä vuonna 1935 käytäntöön otetusta menettelytavasta, että vaimoa on erikseen verotettava kodin ulkopuolelta saadusta ansiotulosta. Perustelut, jotka niin verokomitea kuin hallituskin tämän muutoksen tueksi esittivät, olivat varsin heikot. Sanottiin, että erikseen verotettaessa "puolisot, joista vain toisella on ollut tuloa tai omaisuutta, joutuvat tällöin ankaramman verotuksen alaiseksi kuin puolisot, joilla yhteensä on ollut saman verran tuloa tai omaisuutta». Tätä ajatusta tuskin kuitenkaan on ajateltu lopputun saakka. Jos miehellä on esim. 90.000 markan vuositulot, on luonnollista, että häntä on verotettava raskaammin kuin aviopuolisoja, 
Vuoden 1943 tulo- ja omaisuusverouudistuksen merkitys perheellisille.

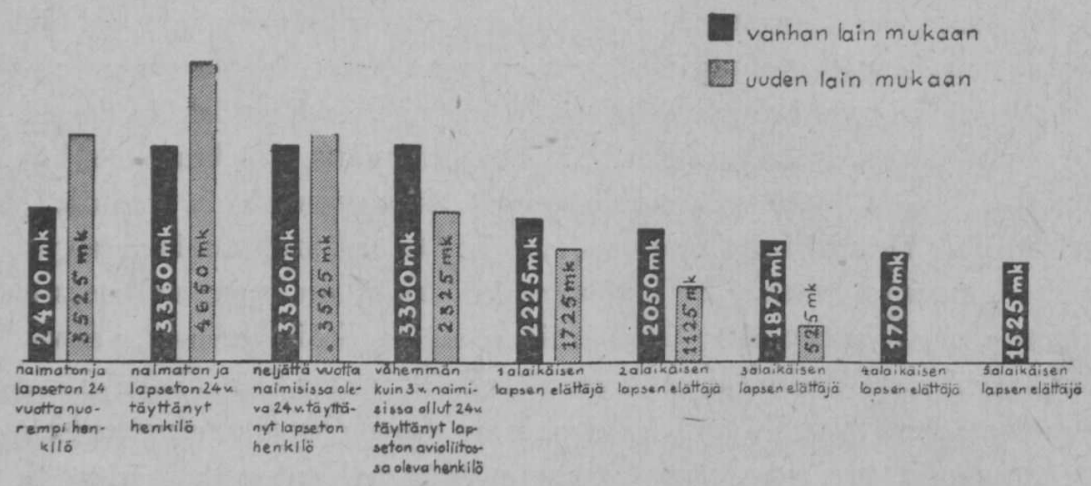

Mustat pylväät: 60.000 markan vuositulosta entisen lain perusteella maksettava tulovero, kun otetaan huomioon perheettömäin lisävero ja lapsivähennykset.

Harmaat pylväät: 60.000 markan vuositulosta vuoden 1943 tulo- ja omaisuusverolain mukaan maksettava vero. Neljän lapsen elättäjä on jo verovapaa.

joilla yhteensä on sama tulo. Verokomiteakin huomaa, että perheessä, jossa vain miehellä on tuloa, vaimon kotitaloudessa suorittama työ on kokonaan verovapaa. Vaikka tätä työtä ei varsinaisesti verolle pantaisikaan, ei sitä kuitenkaan voida perheiden keskeisessä vertailussa olla huomioon ottamatta, jos oikeudenmukaiseen tulokseen pyritään.

Verokomiteakin on pyrkinyt ottamaan huomioon sen, että ansiotyössä oleva vaimo ei ehdi kotitaloudessa tehdä samaa kuin kotona oleva vaimo, vaan että hänen on useasti palkattava vierasta työvoimaa kotiinsa. Tällä kai on perusteltava sitä verokomitean ehdotuksesta uudelleen käytäntöön otettua tapaa, että pienempituloinen aviopuoliso saa vähentää puolet tulostaan, kui- 
tenkin vain määräsummaan, vuoden 1943 laissa 20.000 markkaan saakka. Jos jollakin miehellä on 90.000 markan vuositulot, hän maksaa vuoden 1943 lain perusasteikon mukaan veroa 4.950 markkaa. Jos perhe saa saman tulon siten, että mies saa 60.000 markkaa ja vaimo 30.000 markkaa, se maksaa veroa 75.000 markasta elikkä 3.525 markkaa. Jos aviopuolisoja olisi entiseen tapaan verotettu erikseen, he olisivat yhteensä joutuneet maksamaan 2.925 markkaa. Tämän etuuden verokomitea kuten hallituskin tahtoi ottaa pois, koska, niiden mielestä "puolisot, milloin he molemmat ovat ansiotoimessa, joutuvat kohtuuttoman edulliseen asemaan verrattuna niihin tapauksiin, joissa vain toisella puolisolla on sellaista tuloa».

Mikä pätevyys tällä verokomitean perustelulla on, sen huomaamme, jos palaamme edelleen mieheen, jolla on 90.000 markan tulot ja joka maksaa veroa 4.950 markkaa. Hänen vaimonsa verovapaa työ on arvioitava vähintään 20.000 markaksi. Tätä halvemmilla kustannuksilla ei vuonna 1943 voinut esim. kunnollista kotiapulaista pitää. Todellisuudessa perheen tulo näin ollen on ollut 110.000 markkaa, josta menee asteikon mukaan veroa 7.350 markkaa. Huomaamme tämän perheen siis saavan 2.400 markan verohuojennuksen, kun sitävastoin erikseen verottaminen yhdessä ansainneille aviopuolisoille olisi merkinnyt vain 600 markan lisähuojennusta elikkä 2.025 markan kokonaishuojennusta.

Samaan luokkaan edellisen perustelun kanssa kuuluu verokomitean laatima ja hallituksen hyväksymä jatkoperustelu: »Nykyisen järjestelmän epäkohtana on pidettävä myös sitä, että silloinkin, kun molemmat puolisot ovat ansiotoimessa, heidän veromääränsä vaihtelee suuresti sen mukaan, miten tulo jakautuu puolisoiden kesken. Siten joutuvat puolisot, joilla molemmilla on yhtä suuret tulot, edullisempaan asemaan kuin sellaiset, joilla yhteensä on yhtä suuri tulo kuin edellisillä, mutta joiden kesken ansiotulot jakautuvat siten, että toisella on huomattavasti suurempi tulo kuin toisella». Tämä ilmiöhän johtuu kokonaan siitä, että puolisoiden saadakseen yhdessä kokoon saman summan, minkä toisen perheen päämies pääasiassa yksinään ansaitsee, täytyy kuulua huomattavasti alempiin tuloluokkiin. Edellinen esimerkki sopii myös selittämään tämän ilmiön. 
Progressiivisen asteikon käytössä ei koskaan päästä oikeudenmukaisuuteen, jos samaa asteikkoa yritetään soveltaa toisella kertaa yhden, toisella kertaa useamman henkilön hankkimiin tuloihin. Tällaisen yrittämiseen ei olekaan mitään syytä, sillä kotona olevan vaimon työn verovapaus vastaa kyllä tyydyttävästi sitä vähäistä etua, minkä aviopuolisoiden erikseen verottaminen näille antaa. Epäkohta on vain siinä, että aviovaimon kotona suorittaman työn verovapaudesta johtuva etuus on riippumaton perheen suuruudesta. Päästäisiin oikeudenmukaisempaan verotukseen, jos toisaalla verotettaisiin myös lapsettoman aviovaimon kotitaloudessa tekemää työtä panemalla hänelle ja häneen verrattavalle työkykyisella ihmiselle vähintään määrättyä minimituloa vastaava vero ja toisaalla sallittaisiin suurten perheiden jossakin määrin vähentää kotiapulaisen palkkaa verotettavasta tulostaan.

Maanviljelijäperheen yhteisverotus. Vuoden 1943 tulo- ja omaisuusverotuslakiin sisältyy toinenkin vastaavanlainen korjausta vaativa menettelytapa. Sanotun lain 19 §:ssä näet määrätään, että maataloudessa on kotona työskentelevien 16 vuotta täyttäneiden lasten työn arvo, arvioituna rahassa siihen määrään, mikä tästä työstä olisi palkatulle henkilölle ollut suoritettava, laskettava maatalouskiinteistön tuloksi. Järjestely merkitsee sitä, että mitä suurempi maanviljelijän perhe on ja mitä paremmin se pysyy koossa, sitä korkeamman verokannan mukaan sen on veronsa maksettava. Oikea menettely luonnollisesti olisi se, että jokaista vanhempiensa maataloudessa työskentelevää 16 vuotta täyttänyttä lasta verotettaisiin henkilökohtaisesti siitä määrästä, mikä hänen työstään olisi ollut vieraalle henkilölle maksettava.

Paikallisvähennys. Ennen vuoden 1943 lakia oli ns. kalliin paikkakunnan vähennys kokonaan riippumaton perheen suuruudesta. Niinpä Helsingissä vuoden 1941 tuloista verotettaessa vanhapoika sai tästä vähennyksestä rahallista etua 630 markkaa ja 6 lapsen perhe vain 270 markkaa, jos kummallakin oli 40.000 markan vuositulo. Kun Väestöliiton taholta kiinnitettiin valtioneuvoston huomiota tähän epäkohtaan, saatiin vuoden 1943 lakiin sellainen korjaus, että alennus voi silloin, kun verovelvollinen on elättänyt alaikäistä lastaan, olla enintään 7.500 markkaa, kun se muuten voi olla enintään 5.000 markkaa. Mikäli tällainen vähen- 
nys katsotaan tarpeelliseksi, sikäli olisi luonnollisestikin perheen suuruus otettava paremmin huomioon. Varsinkin kun vähennys, joka aikaisemmin rajoittui pienehköihin tuloihin, vuoden 1943 laissa tuli yleiseksi vähennykseksi. Ei voida pitää oikeana, että yksinäisellä henkilöllä on sama vähennys kuin aviopuolisoilla, joiden nuorin lapsi jo on ehtinyt täyttää kuudennentoista ikävuotensa. Eikä ole oikein, että ensimmäisestä lapsesta voi saada vähennykseen 50 prosentin korotuksen, mutta seuraavista ei mitään, vaikka on aivan selvää, että kalliilla paikkakunnalla asuminen vähentää veronmaksukykyä sitä enemmän, mitä suurempi perhe on. Jos vähennys halutaan säilyttää, se olisi tavalla tai toisella kytkettävä lapsivähennykseen, kuten esim. lainvalmistelukunta vuonna 1934 ehdotti.

Lain yksilapsijärjestelmää suosiva pïrre. Niin monta parannusta kuin vuoden 1943 tulo- ja omaisuusverolaki perheellisten kannalta sisältääkin, sille on kuitenkin oleellista, että se suosii yksilapsijärjestelmää. Esim. henkilö, jonka vuositulo on 75.000 markkaa, joutuu naimattomana maksamaan siitä veroa 7.050 markkaa. Hänen solmittuaan avioliiton putoaa vero pelkän vihkimätodistuksen ansiosta puoleen eli 3.525 markkaan. Jos hän kolmen vuoden aikana saa lapsen tai ottaa kasvatin, tämä alennus säilyy ja hän saa sen lisäksi 750 markan lapsivähennyksen. Seuraavista lapsista hän saa vain 750 markkaa. Kun väestöpoliittisesti on tärkeätä, että ihmisillä yleensä on enemmän kuin $1-2$ lasta, olisi suotavaa, että veroasteikkoa laadittaessa tällaista suurta porrasta ei asetettaisi ensimmäisen, vaan mieluummin kolmannen tai neljännen lapsen kohdalle.

Inflaation vaikutus perheellisten verotukseen. Tulo- ja omaisuusverolakiin on inflaation vaikutus ollut vielä tuhoisampi kuin kunnallisverolakeihin. Ei riitä se, että liian pienet tulot joutuvat verotuksen kohteeksi. Progressiivisen asteikon vaikutuksesta joutuvat kaikki tulot raskaammin verotetuksi kuin mitä lainsäätäjän alkuperäinen tarkoitus oli. Kesä-heinäkuussa 1943, jolloin tuloja omaisuusverolaki oli valmistelun alaisena, virallinen elinkustannusindeksi oli 187. Vuoden 1946 tammikuussa se oli 423. Virallisen elinkustannusindeksin mukaan olivat elinkustannukset siis jo pari kuukautta sitten kohonneet noin 126 prosentilla. Jos tarkastelemme palkkojen nousua, huomaamme nousun olleen jokseenkin 
vastaavan. Rahapalkat ovat toisin sanoen nousseet, mutta reaalipalkat pysyneet suunnilleen samana. Se, jolla aikaisemmin oli 45.000 markan vuositulo ja joka maksoi siitä veroa 3 prosenttia, saa nykyisin vähintään 90.000 markkaa vuodessa. Tulon ostokyky ei ole kasvanut, mutta veroprosentti progressiivisessa asteikossamme on tällä kohdalla 5 1/2.

Tällaista veroprosentin nousua voitaisiin puolustaa viittaamalla valtion lisääntyneeseen rahantarpeeseen, jos se kohtaisi tasaisesti kaikkia veronmaksajia. Näin ei kuitenkaan ole laita. Kun perheen suuruuden huomioon ottaminen tulo- ja omaisuusverotuksessa perustuu eräisiin markkamääräisiin lukuihin, kuten verovapaaseen toimeentulominimiin ja eräisiin vähennyksiin, ja kun toisaalta lapsivähennyksen määrä progression takia ylemmissä tuloluokissa on vähemmän merkitsevä kuin alemmissa, tästä johtuu, että perheellisten verotus on noussut paljon voimakkaammin kuin perheettömien.

Syyskuussa 1945 Väestöliitto kääntyi kirjelmällä valtiovarainministeriön puoleen esittäen käytännöstä poimituilla esimerkeillä, miten perheellisten verotus inflaation johdosta on kohonnut huomattavasti enemmän kuin perheettömien. Vaikka hinta- ja palkkatasossa ei ollutkaan tapahtunut sellaista vakaantumista, että ne absoluuttiset tai suhteelliset luvut, joiden avulla perheellisyysrasitus verotuksessa otetaan huomioon, voitaisiin pitempää aikaa silmällä pitäen määrätä, liitto kuitenkin katsoi, että perheellisten verotus vuoden 1945 tuloista muodostuu kohtuuttoman raskaaksi, ellei mainitun vuoden verotusta varten väliaikaista korjausta saada toimeen.

Kirjelmään liittyvässä muistiossa liitto esitti, että verovapaa toimeentulominimi olisi korotettava vähintään 25.000 markkaan, voitaisiinpa $30.000-35.000$ markankin toimeentulominimiä hyvin puolustaa. Kalliin paikkakunnan vähennys esitettiin siten korjattavaksi, että jokaisesta lapsesta saisi tehdä saman lisävähennyksen, minkä lapsenhuoltaja nyt saa lapsettomaan verrattuna tehdä. Muut tulo- ja omaisuusverolain $29 \S$ :ssä kalliin paikkakunnan vähennyksen ohella säädetyt vähennykset, joiden enimmäismäärät on ilmaistu absoluuttisilla luvuilla, esitettiin korotettaviksi silloista rahan arvoa vastaaviksi. Edelleen huomautettiin muistiossa siitä, 
että lapsivähennys, joka voimassa olevan lain mukaan on 1 prosentti verotettavasta tulosta aina 90.000 markan tuloon asti, kohoaa kyllä tulon noustessa, mutta tämä suhteellinen kohoaminen ei kuitenkaan riitä korvaamaan progression lisääntymistä tulon noustessa. Tämän päämäärän saavuttamiseksi olisi lapsivähennys korotettava ainakin 2 prosenttiin tulosta ja annettava sen kohota 180.000 markan tuloon saakka. Tällainen yksinkertainen korjaus saattaisi perheelliset perheettömiin nähden jokseenkin samaan asemaan, jonka he vuoden 1943 lakia säädettäessä-saavuttivat. Ellei aviopuolisoiden yhteisverotuksesta luovuta, olisi vähemmän ansainneen tulosta tehtävän vähennyksen vähimmäismäärä korotettava vähintään 50.000 markkaan, jotta sillä olisi sama reaalinen merkitys kuin 20.000 markan vähennyksellä vuonna 1943. Nythän kotiapulaisen palkkaneuvoston ohjeiden mukainen palkkaus ylittää 50.000 markkaa vuodessa.

Samassa kirjelmässä Väestöliitto kiinnitti valtiovarainministeriön huomiota niihin tulo- ja omaisuusverolain heikkouksiin, joista edellä on ollut puhe ja joista tärkeimmät ovat jako veroluokkiin, lain yksilapsijärjestelmää suosiva luonne, aviopuolisoiden yhteisverotus ja maanviljelijäin 16 vuotta täyttäneiden lasten verotus yhdessä maatalouskiinteistön kanssa. Kirjelmä ei kuitenkaan johtanut mihinkään tulokseen. Valtiovarainministeriössä tiettävästi oli syyskaudella eräitä tätä koskevia suunnitelmia vireillä, mutta ne eivät ehtineet teoiksi saakka ja tuntuu siltä, ikäänkuin olisi tarkoituksenakin ollut uudistuksen siirtäminen ainakin alkaneeseen vuoteen.

Veron korotus ennen lapsivähennyksen tekoa. Puhuttaessa vuoden 1943 lain huononemisesta ei myöskään sovi sivuuttaa sitä lain oikeudenmukaisuuden tietoista vähentämistä, joka pantiin alulle syksyllä 1944 ja joka äskettäin on uusittu. Marraskuussa 1944 annettu laki vuodelta 1945 maksuunpantavan tulo- ja omaisuusveron korottamisesta nimittäin säätää, että mainittua veroa on korotettava 35 prosentilla, ennenkuin laissa säädetty lapsivähennys tehdään. Tämä merkitsee sitä, että mainittu 35 prosentin korotus painaa perheellistä sitä raskaammin, mitä suurempi perhe hänellä on huollettavanaan. Tämä käy ilmi seuraavasta asetelmasta. 
90.000 markan vuositulosta menevä vero.

$\begin{array}{cccc}\text { Lasten luku } & \begin{array}{c}\text { Perusasteikon } \\ \text { mukainen vero } \\ \text { mk }\end{array} & \begin{array}{c}35 \% \text { o:lla koro- } \\ \text { tettu vero } \\ \text { mk }\end{array} & \begin{array}{c}\text { Korotus } \\ \%\end{array} \\ 0 & 4.950 & 6.682 & 35 \\ 1 & 4.050 & 5.782 & 43 \\ 2 & 3.150 & 4.882 & 55 \\ 3 & 2.250 & 3.982 & 77 \\ 4 & 1.350 & 3.082 & 128 \\ 5 & 450 & 2.182 & 385\end{array}$

Jos korotus laskettaisiin vasta sitten, kun perusasteikon mukaisesta verosta ensin on tehty lapsivähennys, korotus tulisi olemaan kaikille 35 prosenttia. Mikäli olen kuullut, kysymyksessä ei ollut mikään erehdys, vaan lienee asianomaisessa eduskunnan valiokunnassa lakia käsiteltäessä nimenomaan lausuttu se ajatus, että perheelliset joutuisivat vuoden 1943 tulo- ja omaisuusverolain perusteella liian edulliseen asemaan ja tässä on mahdollisuus vaikuttaa vastakkaiseen suuntaan. Tätä käsitystä puoltaa myöskin se, että tämä menettely kaiken sen jälkeen, mitä perheelliset inflaation johdosta ovat joutuneet verotuksessa edellä kuvatuista syistä kärsimään, on joulukuun 20 päivänä 1945 annetulla lailla ulotettu myös vuoden 1946 tuloista maksettavaa veroa koskevaksi.

\section{TILAPÄISVEROT.}

Ylimääräinen tulovero. Tarkasteltavana viisivuotiskautena on säädetty useita tilapäisveroja sekä kaksi niihin verrattavaa pakkolainaa, joiden yhteydessä lainsäätäjä on joutunut ratkomaan kysymystä perheellisyysnäkökohtien huomioon ottamisesta. Merkittävin tilapäisvero on perheellisten kannalta ollut ylimääräinen tulovero, joka on tähän mennessä säädetty neljä kertaa eli vuodesta 1942 lähtien joka vuosi edellisen vuoden tulojen perusteella kannettavaksi. Kolmena ensimmäisenä vuonna sitä kannettiin yli 40.000 markan tuloista, vuodelta 1944 yli 60.000 markan tuloista. Perheen suuruus otettiin kolmena ensimmäisenä kertana huomioon 
myöntämällä 1.500 markan vähennys verosta jokaiselta lapselta, josta verovelvolliselle tulo- ja omaisuusverotuksessa oli myönnetty lapsivähennystä. Neljännellä kerralla vähennys korotettiin 2.000 markaksi.

Ylimääräisessä tuloverossa myönnettiin siis alun perin perheellisyyden perusteella huomattavia etuja. On kuitenkin syytä panna merkille, ettei laki tässä suhteessa ole koskaan ollut väestöpoliittisesti tarkoituksenmukainen. Veroa on kannettu suhteellisen suurista tuloista, joten vähennys ei ole ollut tarpeen sosiaalisista, vaan lähinnä oikeudenmukaisuussyistä. Olisi näin ollen ollut asianmukaista, että siitä olisivat päässeet osallisiksi lähinnä ne, joiden perheellisyysrasitus on minimiä suurempi. Tämä ei kuitenkaan ole ollut mahdollista. Vuonna 1942 säädetty ensimmäinen ylimääräinen tulovero esim. alkoi 40.000 markan tuloista. 80.000 markan tulosta meni veroa 2.800 markkaa. Vielä tähän tuloluokkaan kuuluva, silloisissa oloissa verraten suurituloiseksi katsottava pääsi kokonaan vapaaksi, jos hänellä oli kaksi lasta. Toisin sanoen henkilö, jolla oli neljä lasta, sai havaita, että tästä lapsirunsaudesta ei ollut mitään hyötyä hänelle.

Inflaatio on tätä epäkohtaa jonkin verran lieventänyt. Neljännessä ylimääräisessä tuloverossa, josta toinen puoli kannetaan vasta vuonna 1946, pääsee kahden lapsen huoltaja verovapaaksi vain 100.000 markan tulosta, mikä tietenkin on paljon pienempi tulo kuin 80.000 markkaa vuonna 1942. Puheena olevan suurehkon vähennyksen tarkoituksena on ollut tehdä oikeutta, mutta perheellisille ei tehdä oikeutta yksin sillä, että lapsen elättämisen perusteella myönnetään suuri vähennys. Näiden vähennysten täytyy myös olla oikeassa suhteessa siihen rasitukseen, joka erisuuruisten perheiden huoltajia painaa. Myöskään väestöpoliittiselta kannalta ei ole mitään syytä antaa alennuksia suurituloisille henkilöille, joilla ei ole lapsia muuta kuin minimimäärä. Sensijaan on kyllä tarkoituksenmukaista vähentää suurituloisenkin veronmaksajan taakkaa, jos hänellä on tavallista suurempi perhe.

Ylimääräinen varallisuusvero. Neljänä viimeisenä vuonna on ns. finanssiohjelmaan ylimääräisen tuloveron rinnalla kuulunut myös ylimääräinen varojen perusteella suoritettava vero. Tämä vero on siitä merkittävä, että sen yhteydessä on perheellisyys otettu 
huomioon ainoastaan negatiivisessa mielessä. Samoin kuin tulo- ja omaisuusveron korottaminen vuosina 1944, 1945 ja 1946 on tehty perheelliselle sitä raskaammaksi, mitä suurempi hänen perheensä on, samoin on perheellisten saavutettuja oikeuksia myös ylimääräisen varallisuusveron kohdalla kavennettu. Laki näet sanoo, että verotuksen kohteena on se varallisuus, joka tulo- ja omaisuusverotuksessa on todettu verovelvollisella olevan, kuitenkin niin, että vaimon ja lasten kohdalta ei saa tehdä niitä 50.000 markan suuruisia vähennyksiä, jotka tulo- ja omaisuusverolaissa säädetään.

Toinen omaisuudenluovutusvero. Samanlainen supistus on tehty vuonna 1945 säädettyyn toiseen omaisuudenluovutusveroon. Siinäkään ei saa mainittuja vähennyksiä veronalaisesta omaisuudesta tehdä. Sensijaan on erikseen säädetty, että jokaisesta lapsesta, josta tulo- ja omaisuusverotuksessa on myönnetty lapsivähennystä, saa vähentää 10.000 markkaa. Tuntuu kuin lainsäätäjä suorastaan katuisi, että vuoden 1943 tulo- ja omaisuusverolaissa tuli hyväksytyksi se periaate, että monilapsisen perheen omaisuuttakin olisi verotettava jonkin verran lievemmin kuin huoltovelvollisuutta vailla olevien henkilöiden varoja.

Sotalainat. Edellä kosketeltuihin ylimääräisiin ja tilapäisiin veroihin verrattavia ovat molemmat sotalainat, joista ensimmäinen säädettiin annettavaksi vuoden 1942, jälkimmäinen vuoden 1943 tulon ja omaisuuden perusteella. Ensimmäisessä lainassa, joka oli 5 prosenttia tulosta ja 3 prosenttia omaisuudesta, vähennettiin lainasummasta 500 markkaa jokaiselta tulo- ja omaisuusverotuksessa lapsivähennykseen oikeuttavalta lapselta. Toisessa lainassa, joka oli $5 \frac{1}{1 / 2}$ prosenttia tulosta ja $3 \frac{1 / 2}{2}$ prosenttia omaisuudesta, lapsivähennys oli 1.000 markkaa.

\section{KULUTUSVEROT.}

Useimmille kulutusveroille on ominaista, että ne rasittavat perhettä sitä enemmän, mitä suurempi se on. Perheellisten verotuksen saamiseksi oikeudenmukaiseksi kulutusverotus olisi pyrittävä suuntaamaan etupäässä sellaisten nautintoaineiden kuin alkoholin ja tupakan verotukseen, koska tämänluontoiset kulutusverot 
eivät yleensä rasita perheellistä enempää kuin perheetöntä. Varsinaisiin elintarvikkeisiin kohdistuva kulutusverotus olisi pyrittävä supistamaan mahdollisimman vähiin.

1930-luvun keskivaiheilla muodostivat kulutusverot noin $\mathbf{7 5}$ prosenttia valtion verotuloista, ja noin puolet valtion kaikista verotuloista oli sellaisia kulutusveroja, joiden voi katsoa rasittavan perheellisiä enemmän kuin perheettömiä. Sotavuosina on välittömien verojen osuus varsinkin omaisuudenluovutusverojen ansiosta lisääntynyt. Kulutusverotuksen alalla on kuitenkin otettu käytäntöön uusi johtavaksi kulutusveroksi muodostunut vero, liikevaihtovero, jonka tuotto on hyvin suuri ja josta tuskin enää päästään. Kun ulkomaankauppa toivottavasti lähivuosina vilkastuu ja tullitulot 'kasvavat, meillä on taas edessä kausi, jolloin kulutusverot ovat noususuunnassa ja perheellisten verotus sitä tietä kiristymässä. Sotavuosina ovat mahdollisuudet kulutusverojen vastustamiseen olleet varsin rajoitetut. Tämän taistelun aika on edessäpäin. Jos perheellisiä pyritään verottamaan heidän suorituskykyänsä vastaavasti, on niiden välittömään verotukseen kaivattavien parannusten ohella, joita edellä on esitelty, tärkeätä pitää kiinteästi silmällä kulutusverotuksen kehitystä ja osuutta verotuksen kokonaisrasituksessa.

J.k. Tämän julkaisun painoon mennessä hallitus antoi 15. maaliskuuta 1946 esityksen tulo- ja omaisuusverolain muuttamisesta. Verotettavan tulon alarajaksi I tuloluokassa esitetään 30.000 markkaa, muissa 40.000 markkaa. Lapsivähennys esitetään 2. lapsesta alkaen korotettavaksi kahteen prosenttiin tulosta aina 400.000 markan tuloon saakka, josta alkaen se olisi 8.000 markkaa. Paikallisvähennykseksi esitetään 8.000 markkaa, aviopuolisoilta 12.000 markkaa sekä kultakin lapselta 4.000 markkaa. Vähemmän ansainnut aviopuoliso saisi vähentäessään puolet tulostaan vähentää aina 50.000 markkaan saakka, kun nykyinen raja on 20.000 markkaa. Asteikkoa esitetään korotettavaksi, jotta ylimääräisestä tuloverosta voitaisiin luopua. Kun veron enimmäismäärä eri tuloluokissa nyt on $32,29,5$ ja 26 prosenttia, se tulisi hallituksen esityksen mukaan olemaan 58,53 ja 48 prosenttia. 